\title{
Introduction to the Book Reviews
}

\author{
Sophia Fantus ${ }^{1}$
}

Published online: 22 March 2015

(c) Springer Science+Business Media New York 2015

Four recently published books were selected for review in this special issue. Each book critically examines the novel ways in which technology and social media have reshaped our interpersonal and professional relationships. Sherry Turkle's Alone Together: Why We Expect More from Technology and Less from Each Other, reviewed by Margaret Arnd-Caddigan, and danah boyd's It's Complicated: The Social Lives of Networked Teens, reviewed by Lorraine Tempel, address the general utilization of technology across populations, and explore its impact on quality of life, human connectivity and experiences of isolation. Social Work \& ICT, written by Andrew Hill and Ian Shaw, reviewed by Susan Bliss, and Social Work in a Digital Society, written by Sue Watling and Jim Rogers, reviewed by Brian Rasmussen, guide social work practitioners, educators and students on skillfully integrating technology into social work practice and education.

All four books draw attention to the prevalence of technology and the growing use of social media and online learning environments. The emergence of cybertechnology becomes an important component of social work practice, as online relationships, connections and interactions among our clients become increasingly more frequent. 